\title{
5 Dimensi Dampak Kebijakan Covid-19 Terhadap Sistem Keolahragaan Nasional
}

\section{Dimensions Of Covid-19 Policy Impact On The National Sports System}

\author{
Achmad Gunawan \\ Kementerian Koordinator Bidang Pembangunan Manusia dan Kebudayaan \\ E-mail korespondensi: achmad.gunawan91@ui.ac.id; achm.gunawan@gmail.com
}

\begin{abstract}
Abstrak
Sebagai dampak covid-19, Olimpiade Tokyo ditunda ke tahun 2021, begitu juga dengan penyelenggaraan Piala Eropa (UEFA Cup) 2020 ditunda ke tahun 2021. Di tingkat nasional penyelenggaraan PON XX Papua 2020 yang rencananya dilaksanakan pada Oktober 2020, di tunda ke tahun 2021. Begitupun dengan dihentikannya liga sepokbola Indonesia sejak tanggal 14 Maret 2020. Dari aspek pembudayaan olahraga, prasarana dan sarana olahraga ditutup, gym, lapangan futsal, lapangan tenis, kolam renang umum. Belum lagi dampak terhadap industry alat-alat olahraga. Meskipun begitu, di sisi lain pandemic covid-19 juga mendorong masyarakat untuk memiliki budaya hidup sehat dengan melakukan olahraga rutin secara mandiri. Artinya covid-19 disatu sisi memberikan dampak negatifyang dahsyat, namun di sisi lain juga membawa dampak positif. Dengan melihat dampak cobvid-19 melalui 5 dimensi dampak kebijakan Thomas $R$. Dye, diharapkan dapat dijelaskan dampak covid-19 terhadap system keolahragaan nasional secara utuh, sehingga upaya penanganannya juga dapat dirumuskan dengan kebijakan yang komprehensif dan efektif.
\end{abstract}

Kata Kunci: Covid-19, dampak, dimensi, olahraga

\begin{abstract}
As a result of covid-19, the Tokyo Olympics was postponed to 2021, as well as the implementation of the European Cup (UEFA Cup) 2020 was postponed to 2021. At the national level the holding of the XX Papua 2020 PON, which was planned to be held in October 2020, was postponed to 2021. Likewise with the termination of the Indonesian football league since March 14, 2020. From the aspect of sports culture, sports infrastructure and facilities are closed, gym, futsal court, tennis court, public swimming pool. Not to mention the impact on the sports equipment industry. Even so, on the other hand, the Covid19 pandemic also encourages people to have a culture of healthy living by doing regular exercise independently. This means that Covid-19 on the one hand has had a devastating negative impact, but on the other hand it also has a positive impact. By looking at the impact of Cobvid-19 through 5 dimensions of the impact of Thomas R. Dye's policies, it is hoped that the impact of Covid-19 on the national sports system as a whole can be explained, so that handling efforts can also be formulated with comprehensive and effective policies.
\end{abstract}

Keywords: Covid-19, impact, dimensions, sport 
Jejaring Administrasi Publik, Vol. 12, No. 1, 2020, hal 24-42

\section{Pendahuluan}

Sistem Keolahragaan Nasional diatur dengan UU No. 3 tahun 2005. Di dalamnya, sistem keolahragaan nasional didefinisikan sebagai keseluruhan aspek keolahragaan yang saling terkait secara terencana, sistematis, terpadu, dan berkelanjutan sebagai satu kesatuan yang meliputi pengaturan, pendidikan, pelatihan, pengelolaan, pembinaan, pengembangan, dan pengawasan untuk mencapai tujuan keolahragaan nasional. Tujuannya adalah memelihara dan meningkatkan kesehatan dan kebugaran, prestasi, kualitas manusia, menanamkan nilai moral dan akhlak mulia, sportivitas, disiplin, mempererat dan membina perastuan dan kesatuan bangsa, memperkukuh ketahanan nasional, serta mengangkat harkat, martabat, dan kehormatan bangsa. Kemudian yang menjadi ruang lingkup batasannya adalah meliputi kegiatan olahraga pendidikan, olahraga rekreasi, dan olahraga prestasi. Dari situ jelas sekali bahwa olahraga memiliki spektrum yang sangat luas, jauh melampaui olahraga itu sendiri, pada faktanya olahraga terkait erat dengan kesehatan, ekonomi, sosial, dan budaya, pembangunan karakter, dan bahkan kebanggaan dan nasionalisme. Oleh karena itu penanganan urusan keolahragaan harus dipandang sebagai suatu sistem yang terdiri dari rangkaian sub system yang saling terkait dan tidak mungkin diabaikan. Sehingga ketika covid-19 menjadi pandemi maka dampaknya terhadap dunia keolahragaan menjadi massif dan sistemik.

Secara resmi pada tanggal 2 Maret 2020, Pemerintah Indonesia menyatakan bahwa telah ditemukan 2 kasus positif covid-19 pertama. Sejak saat itu hingga tanggal 31 Mei 2020 atau 90 hari pandemi di Indonesia, worldometers.info mencatat telah terdapat 26.473 kasus positif dengan 1.613 kematian, dengan catatan penambahan kasus positif ditanggal tersebut adalah 700 kasus. Catatan kasus positif tertinggi harian tercatat pada 21 Mei 2020, dengan 973 kasus. Artinya trend penularan masih terus terjadi dan fluktuatif. (Worldometer, 2020)

Terkait upaya penanganannya, selang hampir 2 minggu dari ditemukannya kasus pertama, pada tanggal 13 Maret 2020, Presiden menandatangani Peraturan Presiden No. 7 tahun 2020 tentang Gugus Tugas Percepatan Penanganan Covid-19. Yang menunjuk Kepala Badan Nasional Penanggulangan Bencana sebagai Ketua Pelaksana Gugus Tugas, dan Menteri Koordinator Bidang Pembangunan Manusia dan Kebudayaan (Menko PMK) sebagai Ketua Dewan Pengarah. Gugus Tugas ini juga terdiri dari para Menteri dan Kepala Lembaga terkait, yang ditugaskan mengambil langkah - langkah penanganan secara terpadu dalam gugus tugas sesuai dengan tugas dan fungsinya masing-masing. Kemudian Gugus Tugas juga dibentuk di tingkat provinsi, Kabupaten/Kota, Kecamatan, kelurahan, hingga tingkat RW. Pada tanggal 31 Maret 2020, Presiden menandatangani Keputusan Presiden No. 
Gunawan: " 5 Dimensi Dampak Kebijakan Covid-19 Terhadap Sistem Keolahragaan Nasional"

11 Tahun 2020 tentang Penetapan Kedaruratan Kesehatan Masyarakat Covid-19, dimana ditetapkan bahwa covid-19 sebagai penyakit yang menimbulkan kedaruratan kesehatan masyarakat. Kemudian pada tanggal yang sama Presiden juga menandatangani Peraturan Presiden Pengganti Undang - Undang (Perpu) No. 1 Tahun 2020, tentang Kebijakan Keuangan Negara dan Stabilitas Sistem keuangan untuk Penanaganan Pandemi Covid-19 dan/atau dalam rangka Menghadapi Ancaman yang Membahayakan Perekonomian Nasional dan/atau stabilitas system keuangan. Yang kemudian ditetapkan dengan Undang - Undang No. 2 Tahun 2020. Secara umum, sebagaimana yang disampaikan oleh Menko PMK, Pemerintah menerapkan strategi kebijakan trisula, yaitu pertama, penanganan darurat kesehatan. Kedua, adalah pengamananan dampak sosial, dan ketiga adalah penanganan dampak terhadap perekonomian nasional.

Dampak pandemi sangat dahsyat, dari sisi perekonomian nasional, berdasar data yang disajikan BPS 2020, tercatat bahwa tingkat pertumbuhan ekonomi triwulan I 2020 adalah sebesar 2,97\%, angka ini menurun drastis dibandingkan triwulan I 2019 yang mencapai 5,07\%. Belum lagi data dampak covid-19 yang dicatat Kementerian Tenaga Kerja, dimana per tanggal 20 April 2020 tercatat 2,08 juta pekerja terdampak covid-19 yang dirumahkan, baik dari sektor formal maupun sector informal. Dari sisi APBN, Pemerintah menambahkan dan mengalihkan anggarannya untuk penanganan covid-19, dengan total sebesar Rp. 405,1 $\mathrm{T}$, yang dialokasikan untuk penanganan darurat kesehatan, perluasan jaring pengaman sosial, dan dukungan industry. (Kemenkeu, 2020) Belum lagi dampak sosial penutupan rumah ibadah, pelarangan kegiatan yang melibatkan orang banyak, dan pembatasan pergerakan antar daerah dan transportasi.

Begitu massif dan sistemiknya dampak covid-19 ke seluruh aspek kehidupan bermasyarakat dan bernegara, tentunya memberikan dampak terhadap keolahragaan nasional. Untuk itu, melalui tulisan ini, peneliti mencoba menjelaskan dampak covid-19 terhadap keolahragaan nasional secara komprehensif, sehingga dapat menjadi pertimbangan penentuan kebijakan yang tepat.

\section{Kerangka Teori}

Untuk menjelaskan dampak covid-19 terhadap keolahragaan nasional, peneliti menggunakan pandangan Thomas R. Dye (1972) tentang 5 (lima) dimensi dampak kebijakan publik. 5 dimensi dampak kebijakan publik ini dianggap cukup komprehensif untuk menjelaskan dampak covid-19 terhadap keolahragaan nasional. Ini juga sesuai dengan pandangan (Freeman, 1993) tentang tujuan dasar penelitian dampak kebijakan, yaitu untuk 
memperkirakan "efek bersih" dari sebuah intervensi, dan kejadian lainnya yang mempengaruhi prilaku dan kondisi (Parson, 2008). Oleh karena itu dampak yang dilihat tidak untuk mengukur atau memberi rating implementasi yang memang secara jelas menyampaikan tujuan evaluasi untuk memberi rating terhadap suatu kebijakan sebagaimana yang dikatakan Dunn (2000).

Dye berpandangan bahwa dampak kebijakan dapat dijelaskan secara komprehensif melalui 5 dimensi dampak kebijakan publik, sebagai berikut: (1) Dampak pada masalah sosial dan dampak pada orang-orang yang terlibat/dimensi sasaran, (2) Dampak dampak kebijakan terhadap keadaan atau kelompok diluar sasaran kebijakan/dimensi social dan lingkungan, (3) Dampak yang instan dan dampak yang delay/dimensi waktu, (4) Dampak biaya langsung yang dikeluarkan/dimensi ekonomi, (5) Dampak biaya tidak langsung yang harus ditanggung kelompok/pihak di luar sasaran/dimensi ekonomi yang lebih luas. (Dye, 1972).

Untuk memahami suatu dampak kebijakan publik terhadap suatu fenomena, perlu diidentifikasi faktor - faktor yang muncul sebagai akibat dampak covid, yang kemudian mempengaruhi keolahragaan nasional. Sehingga berikut ini adalah gambar kerangka pikir dampak covid-19 terhadap keolahragaan nasional, yaitu:

\begin{tabular}{|c|c|c|c|}
\hline DAMPAK COVID 19 & ASPEK KEOLAHRAGAAN NASIONAL & $\begin{array}{l}\text { TRISULA KEBIJAKAN BIDANG } \\
\text { OLAHRAGA (USULAN) }\end{array}$ & REKOMENDASI \\
\hline $\begin{array}{l}\text { Ekonomi: } \\
\text { - Nilai rupiah }\end{array}$ & $\begin{array}{l}\text { INFRASTRUKTUR: } \\
\text { - Pembangunan/Renovasi untuk PON \& }\end{array}$ & & \\
\hline $\begin{array}{l}\text { - Refocusing } \\
\text { anggaran }\end{array}$ & $\begin{array}{l}\text { PEPARNAS Papua } 2020 \\
\text { - Perawatan prasarana dan sarana olahraga } \\
\end{array}$ & & \\
\hline $\begin{array}{l}\text { Sosial: } \\
\text { - Social/Physical } \\
\text { Distancing (WFH, } \\
\text { SFH,\#dirumahsaja) }\end{array}$ & $\begin{array}{l}\text { PEMBINAAN PRESTASI: } \\
\text { - Pelatnas } \\
\text { - Pelatda } \\
\text { - Try in dan Try out } \\
\text { - Kegiatan klub olahraga }\end{array}$ & $\begin{array}{l}\text { PROTOKOL PRODUKTIF DAN } \\
\text { AMAN COVID-19 (BIDANG } \\
\text { OLAHRAGA) } \\
\text { - Kegiatan pembinaan olahraga prestasi } \\
\text { - Kegiatan pembinaan olahraga } \\
\text { masyarakat }\end{array}$ & $\downarrow$ \\
\hline transportasi & PENYELENGGARAAN EVENT & & $\begin{array}{l}\text { - Protokol aman covid-19 bidang } \\
\text { olahraga }\end{array}$ \\
\hline $\begin{array}{l}\text { Multievent } \\
\text { Olahraga } \\
\text { Internasional: } \\
\text { - Penundaan }\end{array}$ & $\begin{array}{l}\text { - Penyelenggaraan event olahraga(PON \& } \\
\text { PEPARNAS PAPUA 2020, Liga Sepakbola, } \\
\text { dII) internasional di Indonesia (Tuan Rumah) }\end{array}$ & $\begin{array}{l}\text { EVENT OLAHRAGA } \\
\text { - Nasional dan Internasional } \\
\text { internasional }\end{array}$ & $\begin{array}{l}\text { penyelenggaraan event olahraga } \\
\text { - Arah pembudayaan olahraga } \\
\text { masyarakat } \\
\text { - Bentuk bantuan }\end{array}$ \\
\hline $\begin{array}{l}\text { Olimpiade Tokyo } \\
2020\end{array}$ & $\begin{array}{l}\text { Olahraga Masyarakat: } \\
\text { - Tingkat partisipasi masyarakat dalam }\end{array}$ & & \\
\hline $\begin{array}{l}\text { - Pembatalan } \\
\text { ASEAN Para } \\
\text { Games } 2020 \\
\text { - Penundaan event } \\
\text { olahraga } \\
\text { internasional }\end{array}$ & $\begin{array}{l}\text { Masyarakat/Pekerja Olahraga: } \\
\text { - Atlet, pelatih/official yang sumber } \\
\text { pendapatannya dari olahraga } \\
\text { - UMKM Bidang olahraga }\end{array}$ & $\begin{array}{l}\text { BANTUAN } \\
\text { - Untuk pekerja olahraga (atlet, } \\
\text { pelatih) } \\
\text { - Relaksasi kewajiban UMKM } \\
\end{array}$ & \\
\hline
\end{tabular}

\section{Gambar 1}

Bagan analisis dampak covid-19 terhadap Keolahragaan Nasional 
Gunawan: " 5 Dimensi Dampak Kebijakan Covid-19 Terhadap Sistem Keolahragaan Nasional"

Selanjutnya, sebagai pembanding dampak covid-19 terhadap keolahragaan, akan dijelaskan secara komprehensif terkait hal yang sama yang terjadi di negara lain, berdasarkan kasus yang relevan dari setiap aspeknya. Contohnya penundaan Olimpiade Tokyo 2020, keputusan penundaan dan pelaksanaan kembali kompetisi sepakbola di eropa, dan lain sebagainya. Italia, dimana Italia memiliki dampak yang lebih dahsyat, sektor olahraga yang sistemik, dan telah mengambil langkah maju dalam bidang olahraga di masa pandemi, sebagai respon telah menurunnya penyebaran covid-19 di Italia.

\section{Identifikasi Faktor - Faktor Dampak Covid-19 yang Mempengaruhi Keolahragaan Nasional}

Kebijakan yang telah di ambil Pemerintah tentunya memberikan dampak besar dalam semua aspek kehidupan, termasuk keolahragaan. Dan mengacu pada pandangan (Dye, 1972) bahwa kebijakan publik adalah apa yang tidak dilakukan dan apa yang dilakukan Pemerintah maka dalam konteks covid-19, apa yang dilakukan Pemerintah Indonesia dan tidak dilakukan Pemerintah Indonesia juga merupakan kebijakan publik dalam menangani covid-19 di Indonesia. Sehingga apapun dampak covid-19 yang terjadi di Indonesia merupakn dampak dari kebijakan Pemerintah dalam memanangi covid-19. Terkait dampak, dampak kebijakan adalah kondisi fisik atau sosial yang disebabkan output suatu kebijakan (Dunn, 2000). Kemudian (Islamy, 1997) menyampaikan bahwa dampak kebijakan adalah akibat-akibat atau konsekuensi-konsekuensi yang ditimbulkan dalam pelaksanaan kebijakan. Kemudian sebagaimana yang sudah disampaikan dalam bagan analisis diatas bahwa untuk memahami suatu dampak kebijakan publik terhadap suatu fenomena, perlu diidentifikasi faktor - faktor yang muncul sebagai akibat dampak covid-19 yang kemudian mempengaruhi keolahragaan nasional. Untuk itu selanjutnya akan dijelaskan kondisi yang terjadi sebagai dampak covid19 yang kemudian berpengaruh terhadap keolahragaan nasional, sebagai berikut:

Faktor ekonomi: sudah dijelaskan sebelumnya bahwa dampak covid-19 terhadap perekonomian dunia dan nasional sangat dahsyat. Kemudian penjelasannya terkait dengan bagaimana factor ekonomi memberikan pengaruh terhadap keolahragaan adalah: pertama, gejolak nilai mata uang dunia akibat covid-19 menghambat eksekusi penyediaan peralatan pertandingan dan latihan dari luar negeri. Kedua, refocusing anggaran baik APBN maupun APBD untuk penanganan covid-19 menggerus alokasi anggaran pembinaan olahraga, baik dalam hal anggaran pelatihan maupun anggaran pengiriman atlet yang memang banyak dari event olahraga ditunda penyelenggaraannya. Refocusing juga memungkinkan daerah mengalihkan anggaran perawatan prasarana dan sarana olahraga di daerah sehingga 
prasarana dan sarana olahraga di daerah sangat mungkin terbengkalai. Sementara itu di sisi lain, refocusing APBD juga menyebabkan hilangnya pendapatan para atlet dan pelatih sehingga menjadi pekerja terdampak covid-19. Berdasarkan data yang disampaikan Dirjen Bina Keuangan daerah Kementerian Dalam Negeri, pada tanggal 2 Mei 2020, lebih dari 90\% Provinsi telah melakukan refocusing APBD, dengan total mencapai Rp. 55 T, yang berasal dari APBD Provinsi, Kabupaten, dan Kota. Refocusing APBD secara formal didasarkan pada Instruksi Menteri Dalam Negeri No. 1 Tahun 2020 kepada seluruh Kepala Daerah untuk melakukan percepatan refocusing untuk penanganan covid-19 dan dampaknya. Refocusing juga berpedoman pada Permendagri No. 20 Tahun 2020, tentang Percepatan Penanganan Covid-19 di Lingkungan Pemerintah Daerah. Artinya, refocusing APBD sebagai salah satu dampak ekonomi yang kemudian mempengaruhi keolahragaan nasional, juga merupakan implementasi kebijakan nasional yang harus diikuti oleh Pemerintah Daerah. (Kompas, 2020)

Faktor Sosial dibatasi pada pemberlakuan work from home (WFH), school from home (SFH), physical distancing dan pembatasan transportasi atau pergerakan/mobilitas masyarakat dari satu kota ke kota lainnya. Kebijakan ini berpengaruh terhadap keolahragaan nasional dengan dibubarkannya bentuk pemusatan latihan daerah dalam bentuk yang seharusnya dalam suatu pemusatan latihan ditempat dan waktu tertentu sesuai dengan program pelatihan persiapan prestasi. Para atlet dan pelatih tidak mungkin lagi bertemu secara langsung dalam satu tempat, metode latihan terpaksa dilakukan dengan metode daring, yang jelas tidak akan optimal, terlebih untuk cabang olahraga atau nomor pertandingan yang bersifat kelompok atau beregu. Try out dan try in juga tidak mungkin dilakukan, mengingat semua atlet baik di seluruh daerah dan dunia, masih dalam status waspada covid-19 dengan kebijakannya masing-masing yang tentunya juga tidak mengijinkan dilaksanakannya suatu pertandingan olahraga terlebih dengan atlet yang berasal dari daerah atau negara lain. Pembubaran pelatda atau penundaan event olahraga tentunya berpengaruh pada pendapatan para atlet dan pelatih, terlebih banyak dari atlet daerah yang belum dilindungi oleh jaminan kesehatan. Contoh yang paling ramai dibahas adalah pemotongan gaji hingga $75 \%$ para pemain sepakbola klub peserta liga 1 dan liga 2, bahkan berdasarkan informasi yang disampaikan Asosiasi Pemain Profesional Indonesia (APPI), banyak dari pemain menerima gaji dibawah UMR semenjak liga sepakbola Indonesia di hentikan akibat pandemi. Belum lagi para pihak yang tidak terkait secara langsung namun mendapatkan keuntungan dari berbagai penyelenggaraan event olahraga, khususnya para UMKM dan para pedagang musiman. Secara keseluruhan, berdasarkan data yang disampaikan Menteri Koperasi dan 
Gunawan: " 5 Dimensi Dampak Kebijakan Covid-19 Terhadap Sistem Keolahragaan Nasional"

UMKM, per 9 Mei 2020, terdapat 1.785 koperasi dan 163.713 UMKM terdampak covid-19, dimana di dalamnya juga terdapat UMKM bidang keolahragaan. (Rakyat, 2020).

Dari aspek penyelenggaran event olahraga, pembatasan mobilitas dan pemberlakuan physical distancing jelas sekali berpengaruh terhadap penyelenggaraan event olahraga yang memang kegiatan yang bersifat massal dimana banyaknya berkumpulnya orang - orang, baik peserta maupun penonton di satu lokasi secara masif. Salah satu bukti nyatanya adalah penundaan PON dan PEPARNAS Papua 2020, dimana penyiapan infrastrukturnya pun mau tidak mau akan berpengaruh dalam skala yang berbeda-beda tentunya..

Di sisi lainnya, pemberlakuan PSBB, WFH, SFH dan kewaspadaan terhadap covid19 mendorong masyarakat untuk secara mandiri melakukan olahraga di rumah, atau di daerah sekitar rumah, untuk meningkatkan kebugaran dan daya tahan tubuh dari kemungkinan tertular covid-19. Diyakini bahwa olahraga mandiri yang sederhana yang dilakukan masyarakat di rumah masing - masing dapat meningkatkan partisipasi masyarakat pada kegiatan olahraga, sebagai salah satu ukuran keberhasilan pembudayaan olahraga di masyarakat. Sebagai informasi, bahwa data terakhir yang diperoleh dari BPS 2016, menunjukan bahwa tingkat partisipasi masyarakat dalam berolahraga hanya sekitar $27 \%$, yang diukur dari jumlah penduduk usia 10 tahun keatas yang rutin berolahraga.

Faktor Agenda Event Olahraga Internasional, penundaan Olimpiade Tokyo 2020 tentunya berdampak sistemik bagi seluruh penyelenggaraan event olahraga di seluruh dunia. Setidak terdapat 3 hal penting yang terkait penyelenggaraan olimpiade, yaitu: (1) penundaan Olimpiade akibat dampak covid-19 juga berdampak pada proses kualifikasi atlet - atlet yang dapat bertanding di Olimpiade, dimana kualifikasi juga sebenarnya tidak dapat dilaksanakan. (2) pemusatan latihan persiapan mengikuti Olimpiade Tokyo harus dilakukan dari jauh - jauh hari agar persiapannya bener - benar matang melewati semua program latihan sesuai standar untuk mencapai target, namun pergeseran waktu tentunya akan berdampak pada pergeseran waktu program latihan yang secara fisik dan fsikis akan berpengaruh besar pada atlet yang sedang menyiapkan diri. Dan (3) Terkait dengan dukungan sponsor para perusahaan multinasional berskala besar yang tentunya sudah memiliki agenda, dan akan sulit memberikan dukungan pada waktu yang bersamaan, mengingat biaya sponsorship juga tidak kecil.

\section{Dimensi Dampak Kebijakan Covid-19 terhadap Keolahragaan}

Selanjutnya dijelaskan dampak kebijakan covid-19 terhadap keolahragaan, dengan menggunakan 5 dimensi dampak kebijakan Thomas R Dye, sebagai berikut: 
Dimensi Pertama adalah dampak pada masalah sosial dan dampak pada orang-orang yang terlibat langsung di dalamnya, dimensi pertama lebih pada dimensi sasaran. Sasaran dari kebijakan covid-19 adalah seluruh masyarakat Indonesia secara umum, yang kemudian dibagi kedalam tiga kelompok berdasarkan tiga focus kebijakan, yaitu penanganan darurat kesehatan kepada masyarakat yang tertular, ODP, PDP, dan masyarakat secara umum. Kemudian perluasan jaring pengaman sosial kepada masyarakat terdampak ekonomi, korban PHK, usaha yang mati akibat PSBB, dan lain sebagainya. Dan dunia industri kepada para pengusaha agar proses produksi tetap berjalan demi bergeraknya perekonomian nasional. Untuk mempermudah memahami dampak covid-19 berikut ini adalah bagan dimensi dampak terhadap sasaran:

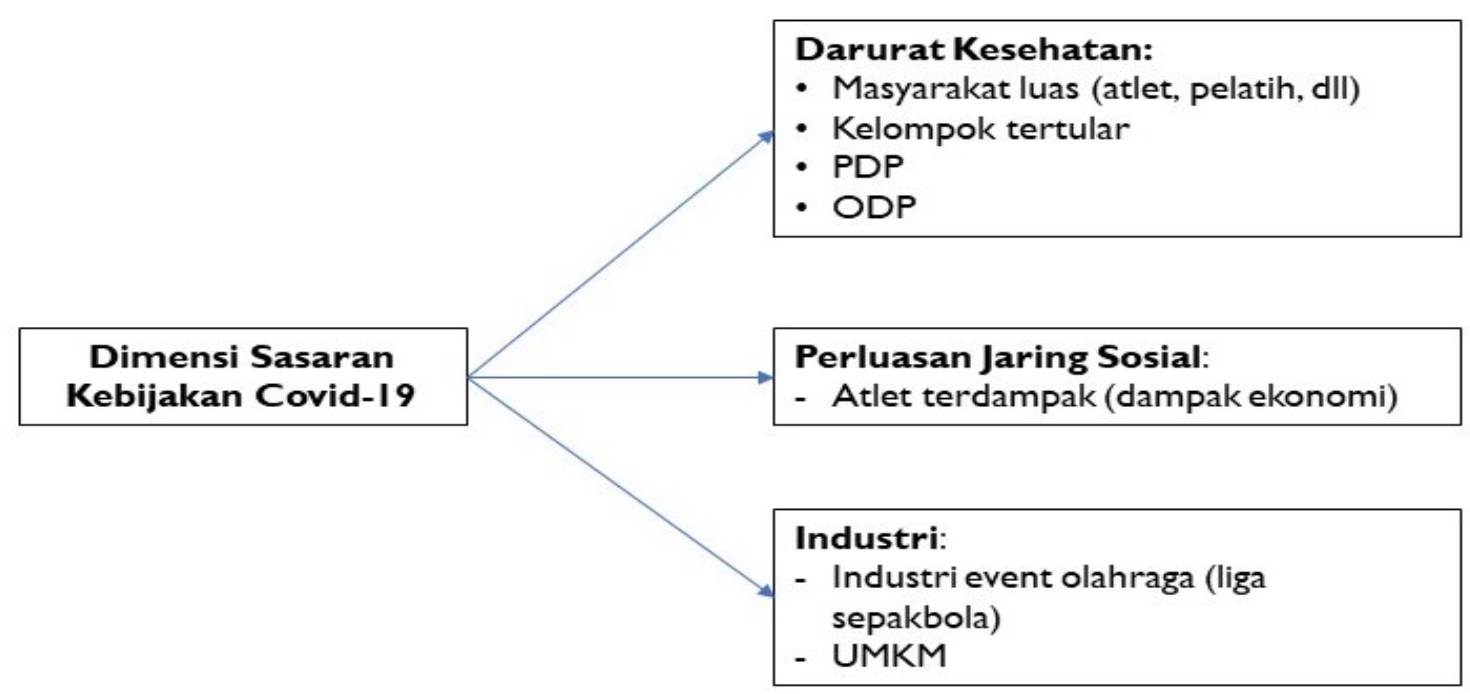

Gambar 2

Bagan Dimensi Dampak Sasaran (Dimensi 1 Dampak Kebijakan Thomas R Dye)

Dari aspek darurat kesehatan, meskipun di seluruh dunia sudah tercatat banyak atlet professional yang terinfeksi covid-19, namun di Indonesia belum ada catatan yang menunjukan atlet Indonesia terinfeksi covid-19. Namun justru dampak ekonomi dan sosialnya justru lebih berat, dimana banyak atlet terkena dampaknya. 360 atlet dalam pemudatan latihan NPC (National Paralympic Committee) dipulangkan. Gaji pemain sepakbola liga Indonesia dipotong hingga 75\%, bahkan ada laporan pemotongan sebesar 90\%. Meskipun tidak didapatkan data tentang jumlah atlet terdampak covid-19 namun banyaknya kegiatan bantuan kepada mereka menunjukan bahwa atlet memang benar - benar menderita sacara ekonomi sebagai dampak covid-19. Beberapa Lembaga keolahragaan 
Gunawan: " 5 Dimensi Dampak Kebijakan Covid-19 Terhadap Sistem Keolahragaan Nasional"

melakukan kegiatan pemberian bantuan sembako bagi para atlet, seperti KONI DIY, NPC Bandung, yang membagikan bantuan sembako kepada para atletnya. Sedangkan terkait dengan dampaknya terhadap industry olahraga, atlet merasakan langsung dengan berkurangnya dukungan sponsor untuk peralatan dan perlengkapan latihan atlet, sebagaimana yang terjadi di Pelatnas Bulutangkis di Cipayung. Penurunan dukungan sponsor dapat dimaklumi karena memang mereka juga mnegalami penurunan pendapatan dari minimnya pendapatan penjualan produk.

Dimensi kedua, dampak kebijakan terhadap keadaan atau kelompok diluar sasaran kebijakan/dimensi sosial dan lingkungan. Dalam konteks ini sesungguhnya satu pihak dapat berada di dua tempat sekaligus, sebagai kelompok terdampak langsung atau pihak di luar system keolahragaan yang terdampak langsung. Sponsor disatu sisi upaya marketingnya terdampak berhentinya pembinaan prestasi olahraga melalui berbagai kompetisi dan event keolahragaan. DI samping itu disisi lain, sebenarnya sponsor juga terdampak langsung dari penurunan hasil penjualannya sebagai dampak ekonomi covid-19.

Masyatakat secara umum juga merupakan kelompok yang secara langsung terlibat dalam penyelenggaraan keolahragaan. Dari konteks industry olahraga, masyarakat adalah konsumen yang kehilangan hiburan tontonan olahraga. Dari konteks masyarakat itu sendiri, mereka adalah pelaku olahraga bagi dirinya sendiri, yang justru terjadi peningkatan kearah positif terkait partisipasi masyarakat dalam berolahhraga di masa kewaspadaan covid-19. Kesadaran masyarakat akan bahaya covid-19 dan pentingnya kesehatan dan kebugaran untuk menjaga daya tahan tubuh mendorong masyarakat untuk berupaya dengan caranya masing masing berolahraga.

Dampak lain terhadap keadaan atau kelompok di luar sasaran adalah para sponsor di baris kedua khususnya yang terkait dengan penanyangan siaran langsung sepakbola dan cabang olahraga lainnya. Sebagai contoh, Djarum Super Socer sebagai salah satu sponsor penayangan siaran langsung sepakbola di Indonesia tentunya terdampak dari aspek promosinya, dan kita ketahui bahwa promosi memiliki keterkaitan sistemik dalam berjalannya suatu perusahaan, meskipun di sisi lain juga perusahaan sesungguhnya terdampak langsung oleh covid-19. Kelompok lainnya adalah pihak - pihak yang tergerak perputaran bisnisnya akibat bergeraknya supporter dari satu kota ke kota lainnya, transportasi dan perhotelan. Baik secara nasional maupun internasional. Kita ketahui bahwa banyaknya kegiatan olahraga rekreasi saat ini banyak menggerekan sector pariwisata.

Dimensi ketiga, adalah dampak yang instan dan dampak yang delay/dimensi waktu. Dimensi ini terkait dengan fungsi waktu. Untuk dampak yang instan dapat jelas terlihat 
betapa penghentian pertandingan liga sepakbola Indonesia langsung memberikan dampak ekonomi yang besar. Namun untuk dampak di waktu mendatang lebih terkait dengan dampak sistemik dari agenda sepakbola lainnya. Tertundanya pertandingan liga sepakbola dan kompetisi cabang popular lainnya seperti bola basket, bola voli, dan bulu tangkis, jelas akan mempengaruhi penyelenggaraan pertandingan yang memang sudah system terbangun dalam agenda besar penyelenggaraan kompetisi di tingkat internasional. Kita ketahui juga bahwa bahwa hampir seluruh cabang olahraga memiliki jadwal yang padat setiap tahunnya, mulai dari kejuaran tingkat daerah, tingkat nasional, tingkat regional, tingkat internasional, kualifikasi olimpiade, dan lain sebagainya. Penundaan akan sistemik dan dari aspek bisnis akan mengubah semua delik kontrak bisnis antara seponsor, pemain, hak siar, dan lain sebagainya. Selain itu, kerusakan dari infrastruktur olahraga juga bisa menjadi dampak yang dirasakan di kemudian hari, karena infrastruktur saat ini banyak tidak terpakai dan sangat mungkin tidak terawat.

Banyak pihak memprediksi bahwa ekonomi akan membutuhkan waktu 4 tahun untuk kembali seperti sedia kala sebagaimana sebelum pandemi covid-19. Oleh karena itu pengukuran dampak dan penggerakan kembali pembangunan bidang keolahragaan juga harus mempertimbangkan kondisi tersebut, sembari mencari kesempatan atau memanfaatkan momentum untuk membangkitkan industry keolahragaan nasional sebagai salah satu komoditas industry yang mendukung perekonomian nasional.

Dimensi keempat, dampak pada dimensi ini adalah biaya langsung yang dikeluarkan/dimensi ekonomi. Contoh terjadinya dampak ini adalah pemotongan gaji pemain sepakbola liga Indonesia hingga $75 \%$ bahkan $90 \%$. Biaya yang dikeluarkan untuk memberikan bantuan sembako bagi para atlet juga menjadi biaya atas dampak dimensi ini. Kemungkinan keuntungan yang diraih dari para supporter yang memenuhi stadion, kemungkinan keuntungan dari hak siar penyiaran langsung, dan kemungkinan lainnya yang hilang akibat pandemic covid-19 adalah biaya yang harus dikeluarkan atas dampak dimensi ini. Belum lagi refocusing anggaran yang dilakukan Pemerintah Pusat dan Pemerintah Daerah kepada anggaran penanganan covid-19.

Dimensi kelima, dampak biaya tidak langsung yang harus ditanggung kelompok/pihak di luar sasaran/dimensi ekonomi yang lebih luas. Penyelenggaraan olahraga bukan sekedar olahraga semata tapi juga merupakan komoditas bisnis, sehingga membangun jaringan yang sangat luas. Kelompok pertama di luar penyelenggaraan olahraga yang terkait dengan dampak covid-19 adalah para sponsor. Penyelenggaraan olahraga di Indonesia dalam konteks sebagai wahana promosi produk dari para sponsor, maka sponsor dengan kondisi ini 
Gunawan: " 5 Dimensi Dampak Kebijakan Covid-19 Terhadap Sistem Keolahragaan Nasional"

kehilangan kesempatan promosi strategisnya ke masyarakat. Kelompok lain adalah para pemegang hak siar yang mendistribusikan siaran pertandingan sepakbola, bola basket, bola voli, bulutangkis, dan siaran olahraga lainnya. Artinya mereka juga kehilangan kemungkinan mendapatkan keuntungan, atau bahkan merugi terkait dengan sumber yang telah dikeluarkan sebagai kegiatan bisnis penyangga yang sudah berjalan. Perlu diketahui bahwa siaran langsung pertandingan olahraga juga membangun jaringan bisnis pemasaran di beberapa level. Pada saat televisi menyiarkan pertandingan olahraga atau cabang olahraga lainnya, maka televisi akan menjualnya kepada para produsen produk untuk menayangkan iklannya, yang artinya ini juga merupakan kegiatan bisnis yang menguntungkan. Kondisi ini menjadi biaya tidak langsung yang harus ditanggung dalam dampak covid-19 terhadap penyelenggaraan olahraga di Indonesia.

\section{Pembelajaran dari Negara Lain (Olahraga di Uni Eropa \& Penundaan Olimpiade Tokyo 2020)}

Pembelajaran dari pengalaman negara lain terkait penyelenggaraan keolahragaan akan dijelaskan secara kasuistis yang terkait dengan kejadian besar di dunia, yaitu penundaan Olimpiade Tokyo 2020, penundaan Liga Sepakbola Eropa, dan beberapa upaya penangannya di beberapa negara.

Secara umum apa yang terjadi di Indonesia juga terjadi di Eropa. Sebagaimana yang tercantum dalam Position Paper on the Impact of the COVID-19 Crisis on the Sport Sector, yang diterbitkan oleh European Platform for Sport Innovation (EPSI). Di dalam position paper tersebut disampaikan bahwa olahraga merupakan sektor ekonomi yang penting di Eropa, bahkan bila dibandingkan dengan sektor pertanian, kehutanan, dan perikanan. PDB terkait olahraga sebesar 279,7 Milyar Euro sama dengan 2,12\% total PDB di Uni Eropa. Di samping itu disampaikan bahwa olahraga bersifat padat karya, yang artinya dapat menyerap lebih banyak tenaga kerja ketimbang sektor lainnya. Setidaknya terdapat 5,67 juta orang bekerja di sektor olahraga. (EPSI, 2020)

Terkait dampaknya, EPSI dalam Position Papernya tersebut menyampaikan bahwa pembatasan mobilitas menghantam sektor olahraga hingga ke intinya. Olahraga professional dan industry olahraga serta seluruh pemangku kepentingannya, atlet, pelatih, instruktur, administrator, sukarelawan, penyelenggara kompetisi, dunia usaha olahraga (pusat kebugaran, gym), event organizer, produsen, dan penyewa alat olahraga, semuanya terkena dampak covid-19. Berikut ini adalah dampak yang dapat diidentifikasi oleh EPSI dalam 
Jejaring Administrasi Publik, Vol. 12, No. 1, 2020, hal 24-42

Position Papernya tentang dampak covid-19 terhadap sektor olahraga, sebagai berikut (EPSI, 2020):

- Organisasi penyelenggara keolahragaan di Eropa banyak yang kehilangan pendapatannya sehingga tidak dapat melaksanakan kegiatan pelatihan dan kompetisi rutin yang biasanya dilakukan.

- Bagi atlet, mereka tidak hanya kehilangan pendapat finansial namun juga kehilangan kemampuan yang mereka dapatkan dengan berlatih dan kompetisi untuk mencapai target tertentu yang juga terkait dengan kemungkinan pendanaan sponsor. Di samping itu atlet juga tidak menerima dukungan keuangan melalui beasiswa, pelatihan, sebagai akibat menurunnya pendapatan organisasi keolahragaan.

- Munculnya pengangguran sebagai akibat adanya PHK karyawan, atlet, pelatih, dan pekerja lain, terutama mereka yang gajinya bergantung pada sumber pendapatan dari kegiatan olahraga, baik dari penonton, siaran, penjualan jersey maupun sponsor.

- Pekerja lepas dan wiraswasta yang sering beroperasi dalam kegiatan event organizer bidang olahraga, tidak dapat melaksanakan sama sekali kegiatannya.

- Di satu sisi, organisasi penyelenggara keolahragaan juga banyak kehilangan pekerja mereka yang tidak dapat melaksanakan pekerjaan mereka karena pembatasan mobilitas baik lockdown atau pembatasan lainnya.

- Industri yang secara langsung dan tidak langsung terkait dengan olahraga melihat bahwa banyak model bisnis yang saat ini gagal dan perlu mengubah strategi bisnis baik dalam jangka pendek maupun jangka panjang, dan ini bisa berpengaruh terhadap potensi keuntungan mereka.

Selain menjelaskan dampaknya, EPSI juga juga menyampaikan beberapa inisiatif dukungan penanganan dampak tersebut, yaitu: pertama, memastikan sektor olahraga memenuhi syarat untuk mendanai perlindungan terhadap pekerja dan wiraswasta terhadap resiko pemecatan dan kehilangan pendapatan. Kedua, meringankan aturan yang berkaitan dengan pajak dan semacamnya. Ketiga, merangsang program inovasi atau modernisasi industry olahraga untuk mengatasi tantangan masyarakat saat ini. Keempat, memberikan pinjaman untuk memastikan likuiditas klub olahraga dan asosiasi lainnya melalui instrument keuangan Uni Eropa, atau instrument yang baru dibuat untuk merespon covid-19. Kelima, mengarahkan aliran dana Uni Eropa kea rah upaya yang mepromosikan kesejahteraan melalui olahraga dan aktivitas fisik. Keenam, Menyiapkan dana solidaritas public dan swasta untuk klub dan asosiasi olahraga masyarakat dan karyawannya, termasuk pelatih dan pekerja lepas. Ketujuh, menciptakan peluang pendanaan baru sebagai cara inovatif untuk 


\section{Gunawan: " 5 Dimensi Dampak Kebijakan Covid-19 Terhadap Sistem Keolahragaan Nasional"}

mepromosikan olahraga terbatas di rumah mereka masing - masing. Kedelapan, membantu sekolah dan guru Pendidikan jasmani untuk terus melatih siswa melalui sarana digital yang efektif dan aman, merangsang inovasi, melalui pendanaan, pedoman, best practices, dan perlakuan khusus biaya internet. Kesembilan, merangsang gaya hidup aktif yang sehat dalam populasi yang bekerja, baik mereka yang bekerja di rumah maupun di kantor dengan meperkenalkan solusi inovatif untuk merangsang aktivitas fisik. (EPSI, 2020).

Tidak berbeda dengan yang terjadi di Italia, sebagaimana yang disampaikan oleh Pisano, Sadun, dan Zanini, dalam artikelnya yang berjudul "Pelajaran dari respon Italia terhadap Coronavirus", yang diterbitkan oleh Harvard Business Review, pada 27 Maret 2020, terdapat 4 kesalahan Italia dalam menangani covid-19. Pertama, Bias Kognitif, para penguasa di Italia dianggap tidak mampu secara sitematis mengidentifikasi saran para ahli tentang bagaimana bertindak pada situasi yang sangat rumit dan tidak ada solusi mudah. Kedua, Solusi Parsial. Ketiga, pentingnya menjadikan pengalaman sebagai pelajaran. Keempat, mengabaikan pentingnya mengumpulkan dan menyebarkan data. (Gary P. Pisano, 2020).

Pada kenyataan dilapangan di bidang keolahragaan khususnya, Ahli epidemiology di Universitas Milan, Prof. Dr. Fabiano Di Marco, yang dicacat Kompas.com pada tanggal 24 April 2020, menyampaikan bahwa salah satu yang diduga kuat menjadi penyebab covid-19 di Italia menyebar dengan sangat cepat adalah pertandingan sepakbola liga champion antara Atlanta melawan Valencia di Stadion Giuseppe Meazza Sansiro di Kota Milan, pada tanggal 19 Februari 2020, dimana lebih dari 40.000 pendukung Atlanta yang berasal dari Kota Bergamo hadir di Kota Milan. Meskipun pertandingan tersebut memberikan hasil yang menggembirakan bagi Atlanta dengan kemenangan telak 4-1 atas Valencia, namun disisi lain justru menjadi bom biologis penyebaran covid-19 di Italia, khususnya di Bergamo dan Kota Milan. Belum lagi pendukung tim tamu Valencia yang datang jauh-jauh dari Valencia Spanyol, yang kemudian kita ketahui juga bahwa Spanyol menjadi salah satu negara yang paling parah mengalami pandemic covid-19 di Eropa. (Kompas.com, 2020).

Dalam proses pengambilan keputusannya, Pemerintah Italia dihadapkan pada ketidakpastian yang luar biasa untuk menentuka apa yang seharus dilakukan untuk menghentikan virus. Virus memang belum secara menyeluruh dipahami sehingga menyulitkan penentuan langkah yang harus diambil, namun disisi lain pemerintah Italia juga lamban dalam menentukan langkah. Di samping itu pendekatan untuk mengambil tindakan membutuhkan upaya mobilisasi sumber dan ekonomi secara ekstrem dan besar-besaran seperti layaknya perang dengan koordinasi ekstrem, baik dari aspek pelayanan kesehatan, 
maupun pengendalian penyebaran, dan penanaganan dampak ekonomi bagi masyarakat. (Gary P. Pisano, 2020) Secara singkat apa yang telah dilakukan Pemerintah Italia dalam menangani covid-19, dianggap lamban, tidak sistemik/parsial, tidak cepat belajar/adaptif belajar dari kegagalan.

Dalam hal tersebut, Indonesia lebih baik, karena telah menghentikan kompetisi lebih cepat dari apa yang dilakukan oleh Italia. Indonesia menghentikan liga sepakbola pada tanggal 14 Maret 2020, 12 hari setelah setelah kasus pertama di Indonesia ditemukan. Sementara Italia mengehentikan liga pada 29 Februari 2020, padahal covid-19 masuk di Italia sejak akhir Januari 2020.

Penundaan Olimpiade Tokyo 2020 juga dapat menjadi pembelajaran bagi penyelenggaraan keolahragaan di Indonesia. Kita ketahui bahwa Indonesia telah mengikuti langkah ini, dimana Presiden melalui Rapat Kabinaet Terbatas, memutuskan untuk menunda penyelenggaraan PON dan PEPARNAS Papua 2020 untuk dapat dilaksanakan di tahun 2021. Namun perlu dijelaskan secara singkat bagaiman Jepang kemudian memutuskan untuk menunda Olimpiade Tokyo 2020, yang memang event olahraga terbesar di dunia, yang akan dihadiri lebih dari 10.000 atlet dari hampir seluruh negara di dunia.

Pada 24 Maret 2020, atau tepat 4 bulan sebelum pembukaan Olimpiade Tokyo 2020, 24 Juli 2020, Perdana Menteri Jepang secara resmi mengumumkan penundaan penyelenggraan Olimpiade Tokyo 2020. Pengumuman ini disampaikan pada saat kondisi pandemic covid-19 di dunia belum dapat di kendalikan. Tercatat di Wolrdometer.info, Jepang sudah mengumumkan kasus pertamanya sejak 15 Februari 2020, dan hingga tanggal 24 Maret 2020 saat penundaan Olimpiade Tokyo 2020 diumumkan, sudah tercatat 1.193 kasus positif covid-19, dengan 43 kematian. Olimpaide Tokyo 2020 adalah gelaran internasional yang akan menghadirkan lebih dari 10.000 atlet dan lebih dari 3,6 juta penonton dari seluruh dunia, sehingga mobilitas dan pengumpulan manusia di suatu tempat tidak bisa dihindari. Sebagai gambaran covid-19 di dunia pada saat penundaan diumumkan, worldometer.info mencatat 423.363 kasus dengan 19.157 kematian di seluruh dunia, dan masih terus bergerak meningkat. (Worldometer, 2020).

Pada awalnya Pemerintah Jepang tidak ingin menunda penyelenggaraan Olimpiade Tokyo 2020, dan bersikeras untuk tetap menyelenggarakannya dengan berbagai penyederhanaan. Hal ini wajar mengingat berdasarkan catatan world economic forum, Jepang sudah berinvestasi sebesar Rp. 199 Triliyun untuk Olimpiade Tokyo 2020. Berdasarkan laporan lainnya, audit Pemerintah Jepang mengatakan bahwa Jepang sudah mengeluarkan biaya untuk Olimpiade Tokyo sebesar 28 Milyar USD. Bagi tuan rumah, 


\section{Gunawan: " 5 Dimensi Dampak Kebijakan Covid-19 Terhadap Sistem Keolahragaan Nasional"}

secara umum penundaan olimpiade berdampak pada, kontrak sponsor, kontrak penyediaan akomodasi, penyediaan transportasi, penyediaan infrastruktur pertandingan, penyediaan infrastruktur dukungan IT dan media, dan persiapan penyambutan penonton dari seluruh dunia yang dilakukan biro - biro perjalanan wisata. Sebagai contoh kecil, Panitia sudah menerima dukungan sponsor 3,3 Milyar USD dari Dentsu.Inc, yang kemudian menanyakan bagaimana penggantian kerjasama akibat penundaan. Di sisi lain Panitia juga harus melakukan negosiasi ulang kepada hotel sebagai akomodasi para kontingen dari seluruh dunia. Belum lagi biaya yang harus dikeluarkan untuk perawatan venue pertandingan dan sarana pendukungnya, yang harus tetap dalam kondisi sempurna satu tahun kedepan. IOC menyatakan akan membantu mangatasi kerugian - kerugian tersebut dengan menganggarkan 800 juta USD atau setara dengan Rp. 11,9 Triliyun Rupiah. Satu hal yang dapat dipelajari dari kasus penundaan Olimpiade adalah penundaan membutuhkan biaya yang sangat besar, namun membatalkan penyelenggaraannnya sama sekali tidak produktif dan merugikan bagi semua pihak.

Pelajaran lainnya yang dapat diambil adalah, bahwa semua pihak meyakini bahwa penyelenggaraan Olimpiade Tokyo 2021 akan membantu jepang mempercepat pertumbuhan ekonominya dimana seluruh dunia melambat akibat pandemic covid-19. Tidak semua negara memiliki kesempatan seperti Jepang, yang akan menjadi negara pertama menyelenggarakan kegiatan sebesar olimpiade pasca pandemic covid-19. Artinya dari aspek ini tuan rumah akan mendapatkan keuntungan kembali setelah banyak hal harus dikorbankan untuk kepentingan keselamatan nyawa manusia sebagai hal utama.

Kondisi ini juga akan terjadi di Indonesia terkait dengan penundaan PON dan PEPARNAS Papua 2020. Berdasarkan catatan Panitia Besar PON, seluruh venue pertandingan akan sudah selesai $100 \%$ pada Agustus 2020, dan siap digunakan sebelum pembukan PON pada 20 Oktober 2020. Begitu juga dengan pembangunan penyiapan dukungan akomodasi dan tranportasi yang sudah dianggarakan oleh Kementerian PUPR dan Kementerian Perhubungan di tahun 2020. Untuk penyiapan rumah susun sebagai dukungan akomodasi PON tetap dilanjutkan dalam kondisi kewaspadaan PON. Namun penyiapan transportasi tidak dapat dilakukan karena dalam bentuk kontrak atau sewa penyediaan bus bus untuk transportasi para kontingen selama di Papua. Meskipun sponsor dan dukungan anggaran tidak semasif Olimpiade Tokyo, namun kerugian penundaan PON juga akan dirasakan beberapa bulan kedepan, dimana catatan itu belum didapatkan mengingat semua pihak masih focus pada penanganan covid-19. 
Jejaring Administrasi Publik, Vol. 12, No. 1, 2020, hal 24-42

Yang menjadi pertimbangan penundaan PON adalah belum dapat dipastikan apakah Oktober 2020, pandemic covid-19 sudah dapat diatasi. Kemudian terhentinya Pelatda seluruh daerah yang menyebabkan tidak akan ada kompetisi yang maksimal di PON 2020. Pengalihan anggaran daerah terhadap anggaran latihan dan pengiriman kontingen. Dan Panitia Daerah yang focus pada penanganan covid-19 sehingga semua persiapan penyelenggaraan PON tidak optimal. (PMK, 2020).

Sebagai informasi, penyelenggaraan PON Papua 2020 akan diselenggarakan pada 20 Oktober - 2 November 2020. PON akan menghadirkan lebih dari 7000 atlet dari 34 Provinsi, yang akan bertanding di 4 Kabupaten yang akan bertanding di 4 kabupaten dan kota di Papua, yaitu Kota Jayapura, Kabupaten Jayapura, Kabupaten Timika, dan Kabupaten Merauke. Berbagai keterbatasan infrastruktur di Papua, memerlukan upaya lebih dari Pemerintah untuk memberikan dukungan terhadap penyelenggaraan PON dan PEPARNAS Papua 2020. (PMK, 2020)

Kembali pada kasus Olimpiade Tokyo 2020, yang menjadi kesempatan bagi tuan rumah untuk mempercepat perekonomiannya, begitupun juga penyelenggaraan PON dan PEPARNAS Papua 2020 akan menjadi pengungkit awal perekonomian nasional di tahun 2021. Beruntungnya Indonesia di tahun 2021 juga akan menjadi tuan rumah Penyelenggaraan Piala Dunia Sepakbola Kelompom Usia U20, yang merupakan juga event olahraga besar tingkat dunia yang akan diikuti oleh 24 negara peserta dari 5 benua. Belum lagi penyelenggaraan Moto GP 2021 yang akan melibatkan Sirkuit Mandalika sebagai salah satu sirkuit seri Moto GP Dunia tahun 2021. Belajar dari Asian Games 2018, meskipun Indonesia mengeluarkan biaya besar untuk penyiapan infrastruktur, namun infrastruktur tersebut bisa bermanfaat dalam jangka waktu yang sangat Panjang, dimana infrastruktur umum untuk keperluan masyarakat luas, maupun secara khusus, venue - venue olahraga untuk pembinaan olahraga. Belum lagi keuntungan finansial, dimana berdasarkan catatan Bappenas (2018), bahwa Asian Games memberikan kontribusi terhadap tingkat pertumbuhan ekonomi nasional mencapai $0,05 \%$, dari 5,15\% menjadi 5,5\%, dengan nominal keuntungan ekonomi sebagai dampak langsungnya adalah Rp, 40,6 Triliyun dengan rincian Rp. 29,1 untuk penyiapan infrastruktur, Rp. 7,8 Triliyun untuk biaya penyelenggaraan, dan 3,7 Triliyun pengeluaran wisatawan manca negara dan wisatawan lokal. Artinya, penyelenggaraan event olahraga memang dapat diandalkan untuk meningkatkan pertumbuhan ekonomi dengan bergeraknya perekonomian secara massif. Dan Indonesia memiliki 3 event olahraga besar di tahun 2021 yang harus dimanfaatkan secara optimal untuk kebangkitan perekonomian pasca covid-19. 
Gunawan: " 5 Dimensi Dampak Kebijakan Covid-19 Terhadap Sistem Keolahragaan Nasional"

\section{Kesimpulan}

Berdasarkan pembahasan diatas disimpulkan, 5 dimensi dampak kebijakan Thomas R Dye dapat menjelaskan dampak secara menyeluruh, baik dari aspek keterlibatan, aspek fungsi waktu, dan aspek biaya yang harus ditanggung sebagai dampak covid-19. Covid-19 memberikan dampak yang sangat luas terhadap bidang keolahragaan di seluruh dunia termasuk Indonesia. Khususnya sebagai pembanding sebagaimana yang terjadi di Uni Eropa. Beberapa aspek yang terkena dampak langsung covid-19 adalah dukungan sponsor, penyelenggaraan kompetisi, pelaksanaan latihan, perjanjian kontrak hak siar pertandingan, operasional pusat kebugaran dan lapangan olahraga, dan kehidupan para pelaku olahraga, atlet, instruktur, pelatih, dan lain sebagainya.

Di Indonesia, seluruh Pemusatan latihan daerah terhenti, beberapa Pelatnas dilakukan melalui metode daring. Terputusnya penghasilan sebagai atlet dan pelatih menempatkan beberapa atlet daerah untuk dapat bantuan sosial dari berbagai pihak khususnya Pemerintah. Perawatan venue berpotensi untuk terabaikan dan penyelenggaraan keolahragaan lainnya di daerah mengingat anggaran daerah banyak dialihkan untuk penanganan covid-19.

Di bandingkan dengan Italia dan negara Eropa lainnya, Indonesia memiliki respon yang lebih cepat dalam bidang keolahragaan, yang dibuktikan dari keputusan penundaan pertandingan liga sepakbola Indonesia 12 hari setelah kasus pertama diumumkan, dimana sebagai pembanding, Italia memutuhkan waktu 1 bulan lebih untuk menunda liga sepakbola Italia.

Sebagai pembanding lainnya, Jepang dan IOC sepakat menunda Olimpiade Tokyo 2020 untuk dilaksanakan di tahun 2021. Kerugian besar dapat dipastikan akan dialami panitia, IOC, dan Pemerintah Jepang. Namun disisi lain Olimpiade Tokyo 2021 akan menjadi pengungkit signifikan perekonomian Jepang pasca covid-19 di tahun 2021.

Indonesia memiliki sedikitnya 3 event olahraga besar di tahun 2021, PON dan PEPARNAS Papua 2021 yang seharusnya dilaksanakan Oktober 2020, Piala Dunia U20 Tahun 2021, dan Moto GP Mandalika 2021. Semuanya harus dimanfaatkan secara optimal untuk kebangkitan perekonomian nasional sekaligus kebangkitan olahraga nasional pasca covid-19.

\section{Rekomendasi}

- Semua pihak harus mengambil langkah - langkah penting untuk mengatasi dampak covid19 pada bidang keolahragaan. Khususnya dari aspek ekonomi dimana banyak atlet dan pelatih harus kehilangan pendapatannya, begitu juga pekerja olahraga lainnya. Terkait 
dengan industry keolahragaan, event organizer, produsen peralatan, dan UMKM olahraga perlu mendapat perhatian untuk mendapatkan berbagai relaksasi.

- Pengembangan protocol produktif dan aman covid-19 bidang olahraga, yang mendorong penyelenggaraan olahraga secara bertahap dengan memperhatikan kewaspadaan covid19, bagi atlet, pelatih, penyelenggara, penonton, bahkan masyarakat, dan dunia pendidikan.

- Segera mempelajari metode new normal dalam bidang keolahragaan, baik dari aspek atlet, proses pelatihan, prasarana dan sarana kebersihan di pusat latihan dan venue pertandingan, maupun keterlibatan penonton.

- Perlu pengembangan metode daring yang efektif untuk proses pelatihan bagi para atlet dan pelatih, sehingga latihan tetap dapat dilakukan. Untuk olahraga masyarakat juga perlu memberikan arah yang tepat bagi masyarakat untuk melakukan olahraganya masing masing.

- Menyiapkan langkah yang tepat yang melibatkan semua unsur termasuk masyarakat untuk mengoptimalkan manfaat penyelenggaraan event olahraga nasional dan internasional di Indonesia sebagai pengungkit kebangkitan perekonomian pasca pandemic covid-19.

\section{Daftar Pustaka}

BPS. (2020, 05 05). pressrelease. Diambil kembali dari www.bps.go.id: https://www.bps.go.id/pressrelease/2020/05/05/1672/februari-2020--tingkatpengangguran-terbuka--tpt--sebesar-4-99-persen.html

Dunn, W. N. (2000). Pengantar analisis kebijakan publik. Yogyakarta: Gajah Mada University Press.

Dye, T. R. (1972). Understanding Public policy. Englewood Cliffs: Prentice Hall.

EPSI. (2020, 03 03). Position Paper On The Impact Of The Covid-19 Crisis On The Sport Sector. Diambil kembali dari https://epsi.eu: https://epsi.eu/news/position-paper-onthe-impact-of-the-covid-19-crisis-on-the-sport-sector/

Forum, W. E. (2020, 04 07). agenda. Diambil kembali dari www.weforum.org: https://www.weforum.org/agenda/2020/04/japan-covid-19-situation-andcoronavirus-impact/ 
Gunawan: " 5 Dimensi Dampak Kebijakan Covid-19 Terhadap Sistem Keolahragaan Nasional"

Freeman, P. H. (1993). Evaluation : a systematic approach / Peter H. Rossi and Howard E. Freeman. London: SAGE Publications.

Gary P. Pisano, R. S. (2020, Maret 27). Lessons from Italy's Response to Coronavirus. Diambil kembali dari https://hbr.org: https://hbr.org/2020/03/lessons-from-italysresponse-to-coronavirus

Islamy, I. (1997). Prinsip-prinsip perumusan kebijaksanaan negara. Yogyakarta: Bumi Aksara.

Kemenaker. (2020, 04 22). news. Diambil kembali dari www.kemnaker.go.id: https://www.kemnaker.go.id/news/detail/menaker-badai-pasti-berlalu-panggilkembali-pekerja-yang-ter-phk-nanti

Kemenkeu. (2020, 05 26). covid19. Diambil kembali dari www.kemenkeu.go.id: https://www.kemenkeu.go.id/covid19

Kompas. (2020, 04 13). read. Diambil kembali dari www.kompas.com: https://nasional.kompas.com/read/2020/04/13/13490351/kemendagri-93-persendaerah-telah-realokasi-apbd-untuk-tangani-covid-19

Kompas.com. (2020, Maret 24). Profesor Universitas Milan Ungkap Salah Satu Penyebab Penyebaran Covid-19 di Italia. Diambil kembali dari https://bola.kompas.com: https://bola.kompas.com/read/2020/03/24/22000038/profesor-universitas-milanungkap-salah-satu-penyebab-penyebaran-covid-19-di?page=all

Parson, W. (2008). Public Policy: pengantar teori dan praktik analisis kebijakan. Jakarta: Kencana.

PMK, K. (2020). Kajian Dampak Covid-19 terhadap Waktu Penyelenggaraan PON dan PEPARNAS Papua 2020. Jakarta: Kemenko PMK.

Rakyat, P. (2020, 05 09). ekonomi. Diambil kembali dari www.pikiran-rakyat.com: https://www.pikiran-rakyat.com/ekonomi/pr-01379615/1785-koperasi-dan-163713umkm-terdampak-pandemi-covid-19

Worldometer. (2020, Mei Minggu). Coronavirus. Diambil kembali dari https://www.worldometers.info:

https://www.worldometers.info/coronavirus/country/italy/ 